\title{
Communities of the Molinio-Arrhenatheretea class in the Biysk-Chumysh Upland region (Altai Krai)
}

\author{
N.V. Ovcharova", A.V. Matsyura \\ Altai State University, pr. Lenina 61, Barnaul, 656049, Russia \\ *Corresponding author E-mail: ovcharovanw@mail.ru, amatsyura@gmail.com
}

Received: 15.09.2020. Accepted 20.10.2020

\begin{abstract}
The article reveals the study of the syntaxonomic diversity of meadow vegetation in the Biysk-Chumysh Upland region (Altai Krai) based on the analysis of 230 complete geobotanical descriptions. The levels of hydration and use (grazing, idle land) are proved to be the main ecological factors. The variety of the Molinio-Arrhenatheretea class in the Biysk-Chumysh Upland (Altai Krai) is represented by three orders. The Molinietalia order is representative of wet meadows, whose floristic composition is mostly comprised of water resistant species. The Arrhenatheretalia order is representative of well-hydrated meadows. The Galietalia veri encompasses the communities of steppe meadows, the cenoflora of which unites the species of true meadows and meadow steppes.
\end{abstract}

Keywords: Vegetation; Meadows; Classification; The Biysk-Chumysh Upland

\section{Introduction}

The Biysk-Chumysh Upland is divided by a well-developed valley-ravine network and has the characteristics of an undulating plain, the height of which gradually increases from 280-300 $\mathrm{m}$ in the north to 350-400 $\mathrm{m}$ in the south. The slopes of the ravines have a complex stepped section, indicating several cycles of the erosion network breakthrough (Zyatkova, 1977). The surface of the flat land on the right bank of the Ob river is dissected by the valleys of the rivers that carry water to the Ob from the Biysk-Chumysh Upland. The territory includes the Ob floodplain with tributaries, oxbowx, swampy sandy terraces (Bazilevich, Shavrygin, 1959).

The climate of the Biysk-Chumysh Upland is characterized by continentality. Precipitation amounts to $400-500 \mathrm{~mm}$ (165-170 mm out of which account for May - July) (Rozanov, 1959). On the whole, the well-drained territory of the Biysk-Chumysh Upland is the reason for the development of a relatively homogeneous soil cover with very strict and simple interdigitation of soil varieties along the relief elements (zonal soil type on watersheds; hydromorphic types in the valleys; forest soils or eroded variants of zonal soil type along the slopes of erosive forms) (Kravtsova, 1959; Omelyanov, 1973). Most of the territory here is composed of the Lower Quaternary sands, overlaid by a thick blanket of loess loams, except for the ancient terraces of the Ob, where the rocks of the Middle Quaternary age are analogous to the sediments on the Priob plateau. Leached chernozems found on the Biysk-Chumysh Upland and on the right bank of the Chumysh river are especially widespread (Rozanov, 1959).

The information on the vegetation of the Biysk-Chumysh Upland (within the territory of Altai Krai) is scarce and is covered in the works of P. P. Polyakov (1934), V. D. Alexandrova, N. P. Guricheva, L. I. Ivanina (1958), A. V. Ronginskaya (1963), G. G. Sokolova (2002), N. V. Ovcharova, S. M. Yamalov (2013), N. N. Makunina, A. Yu. Korolyuk, T. V. Maltseva (2010).

According to the geobotanical zoning by A. V. Kuminova, T. A. Vagina, E. I. Lapshina (1963) the flat part of the Ob river right bank belongs to the subprovince of the Right-Bank Priob forest steppe, the Biysk-Chumysh forest steppe district. According to the scheme of the geobotanical zoning of Altai Krai (Aleksandrova, Guricheva, Ivanina, 1958), the territory under study belongs to the subzone of the middle forest steppe on leached chernozems and gray forest soils.

The purpose of this work was to identify the syntaxonomic diversity of vegetation of the Molinio-Arrhenatheretea class on the BiyskChumysh Upland (Altai Krai).

\section{Materials and Methods}

The work is based on 230 complete geobotanical descriptions made by N. V. Ovcharova, T. A. Teryokhina, N. V. Elesova on the territory of 5 districts within Altai Krai (Kosikhinskiy, Troitskiy, Zonalniy, Biyskiy, Tselinniy districts) (Figure 1).

Geobotanical descriptions were made on the $10 \times 10 \mathrm{~m}^{2}$ sites. The contribution of species into the vegetation cover was assessed according to the Braun-Blanquet scale (Mirkin, Naumova, Solomeshch, 2001): $r$ - single samples of the species were found on the site; + - the projective cover of the species accounts for up to $1 \% ; 1$ - the species has a projective cover of 1 to $5 \%$; 2 - from 5 to 25\%; 3 - from 25 to 50\%; 4 - from 50 to $75 \% ; 5-75 \%$ and more. When compiling synoptic tables, the constancy scale was used: r- 0.1-5\%; + - 6-10\%; I - 11-20\%; II - 21-40\%; III - 41-60\%; IV - 61-80\%; V - 81-100\%.

We created a database of geobotanical descriptions, based on the TURBOVEG program (Hennekens, 1996). The classification was carried out with the application of the ecological-floristic approach (Westhoff, van der Maarel, 1973; Dierschke, 1994) using the JUICE 7.0 software package. (Tichý, 2002). The nomenclature of syntaxonomic units is made in accordance with the Code of phytosociological nomenclature (Weber et al., 2000). To define and describe syntaxons, we used diagnostic species, which include a combination of characteristic differential and constant species (Westhoff, van der Maarel, 1973).

Meadow vegetation of the studied area is used for haymaking and grazing; some meadows represent idle land phytocenoses of various ages. When characterising each syntaxon, the type of use (haying, grazing, idle land) is specifically mentioned. 


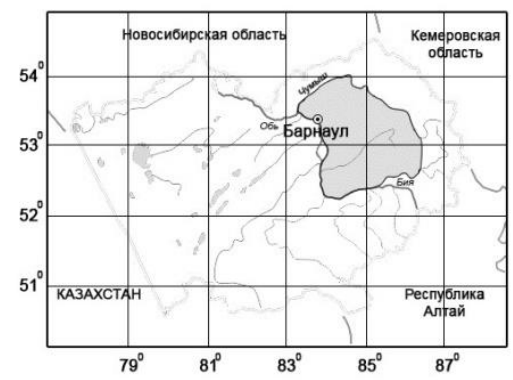

area under study

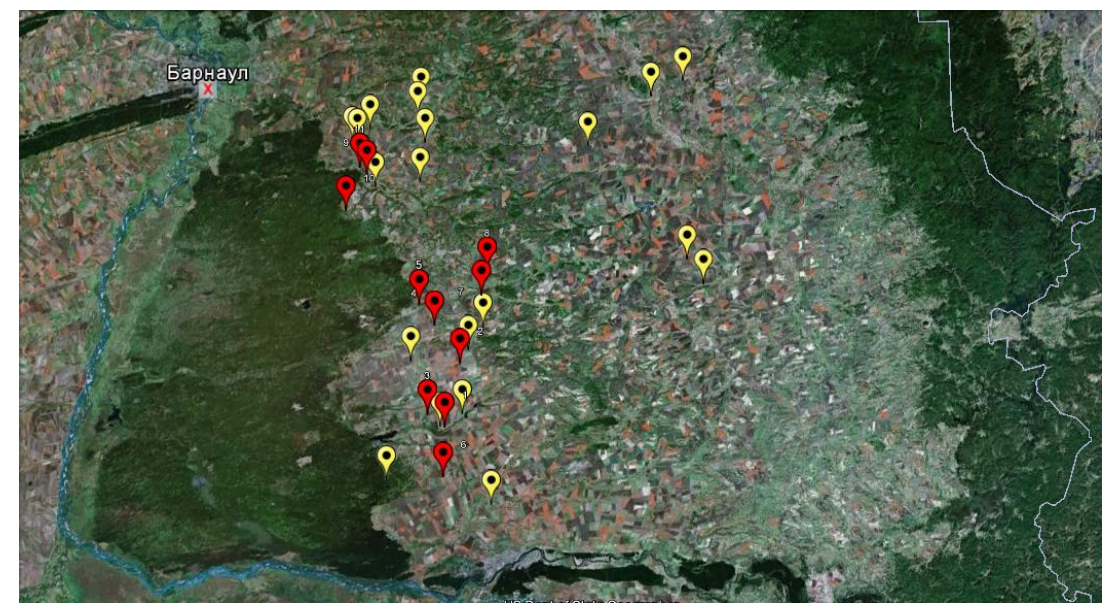

Figure 1. Location of key sites (red dots) and sites where route studies were performed (yellow dots) on the territory of Altai Krai.

\section{Results}

Syntaxonomic analysis of the Molinio-Arrhenatheretea class communities on the territory of the Biysk-Chumysh Upland (Altai Krai) revealed 1 association, 9 rankless communities of 3 orders. The prodromus features the identified units and their position in the system of higher units, according to the prodromus of the Russian vegetation (Ermakov, 2012) (Table 1).

\section{Prodromus of the Molinio-Arrhenatheretea class communities}

Class MOLINIO-ARRHENATHERETEA R. Tx. 1937

Order MOLINIETALIA Koch 1926

Potentillion anserinae R. Tx. 1947 alliance Community Agrostis stolonifera

Order ARRHENATHERETALIA R. Tx. 1931

Festucion pratensis Sipajlova et al. 1985 alliance Festuco pratensis-Dactyletum glomeratae Dymina in Maltseva et Macunina 2008 association Community Bromopsis inermis

Community Poa pratensis

Community Agrostis clavata Community Agrostis tenuis

Order GALIETALIA VERI Mirk. et Naumova 1986

Trifolion montani Naumova 1986 alliance Community Poa angustifolia Community Elytrigia repens Community Nonea pulla-Poa angustifolia Community Vicia amoena-Poa angustifolia

Table 1. Abridged synoptical table of the Molinio-Arrhenatheretea class communities.

\begin{tabular}{|c|c|c|c|c|c|c|c|c|c|c|}
\hline Syntaxon number & 1 & 2 & 3 & 4 & 5 & 6 & 7 & 8 & 9 & 10 \\
\hline Number of descriptions & 8 & 21 & 12 & 12 & 23 & 8 & 29 & 26 & 20 & 19 \\
\hline Average number of species per $100 \mathbf{~ m}^{2}$ & 22 & 19 & 16 & 20 & 21 & 16 & 18 & 21 & 22 & 19 \\
\hline Use & $\mathrm{H}$ & $\mathrm{P}$ & $\mathrm{P}$ & $\mathrm{P}$ & $\mathrm{P}$ & $\mathrm{P}$ & $\mathrm{P}$ & $\mathrm{H}$ & IL,P & $\mathrm{IL}, \mathrm{P}$ \\
\hline \multicolumn{11}{|c|}{ D.s. of Poa angustifolia community } \\
\hline Poa angustifolia & . & II & II & $V^{2-3}$ & I & II & $r$ & II & $\mathrm{V}^{\mathrm{r}-3}$ & $V^{2-4}$ \\
\hline \multicolumn{11}{|c|}{ D.s. of Agrostis tenuis community } \\
\hline Pimpinella saxifraga & II & r & . & II & $\mathrm{V}^{\mathrm{r}-3}$ & . & I & II & . & + \\
\hline Plantago lanceolata & . & . & + & I & IV & . & . & . & . & . \\
\hline Trifolium arvense & . & . & . & II & IV & . & . & . & . & . \\
\hline Lotus ucrainicus & . & . & . & . & III & . & . & . & . & . \\
\hline \multicolumn{11}{|c|}{ D.s. of Elytrigia repens community } \\
\hline Elytrigia repens & I & IV & II & III & r & $V^{2-3}$ & I & $r$ & $r$ & II \\
\hline Festuca pseudovina & . & . & + & . & . & III & . & . & . & . \\
\hline \multicolumn{11}{|c|}{ D.s. of Agrostis clavata community } \\
\hline Agrostis clavata & . & . & + & . & . & . & $\mathrm{V}^{\mathrm{r}-3}$ & . & . & . \\
\hline
\end{tabular}




\section{Amoria hybrida}

Dactylis glomerata

Nonea pulla

Vicia amoena

Filipendula vulgaris

Phlomoides tuberosa

Fragaria viridis

Trommsdorfia maculata

Trifolium pratense

Stellaria graminea

Vicia cracca

Achillea millefolium

Phleum pratense

Galium mollugo

Leucanthemum vulgare

Plantago media

Ranunculus polyanthemos

Agrostis gigantea

Festuca pratensis

Lathyrus pratensis

Carum carvi

Medicago falcata

Centaurea scabiosa

Galium verum

\section{D.s. of Festuco pratensis-Dactyletum glomeratae association}

$\begin{array}{llllll}V & V & \text { III } & \text { II } & r & \text { II }\end{array}$

D.s. of Nonea pulla-Poa angustifolia community

II $r$ II II $r$ I

D.s. of Vicia amoena-Poa angustifolia community

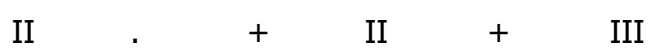

D.s. of Molinio-Arrhenatheretea class

$\begin{array}{llllllllll}\text { IV } & \text { III } & \text { II } & \text { III } & \text { V } & \text { IV } & \text { II } & \text { V } & + & . \\ \text { IV } & \text { IV } & \text { III } & \text { II } & \text { IV } & \text { I } & \text { V } & \text { III } & \text { II } & \text { II } \\ \text { V } & \text { III } & \text { III } & . & \text { IV } & \text { I } & \text { III } & \text { III } & \text { III } & + \\ \text { II } & \text { II } & \text { III } & \text { I } & \text { II } & . & \text { II } & \text { I } & \text { II } & \text { II } \\ \text { II } & \text { IV } & \text { III } & \text { II } & \text { I } & \text { II } & \text { III } & \text { IV } & . & \text { I } \\ \text { I } & + & + & + & \text { III } & \text { IV } & \text { II } & \text { IV } & \text { I } & \text { II } \\ \text { III } & \text { II } & + & . & \text { II } & . & \text { IV } & \text { IV } & \text { II } & \text { I } \\ \text { II } & \text { I } & \text { II } & \text { III } & \text { I } & \text { I } & . & \text { r } & \text { III } & \text { I } \\ \text { II } & \text { II } & . & + & + & . & \text { II } & \text { I } & \text { I } & + \\ \text { I } & . & . & . & . & . & . & \text { r } & . & . \\ \text { IV } & \text { r } & . & \text { I } & + & \text { I } & . & \text { II } & . & . \\ \text { II } & . & . & . & \text { r } & . & . & \text { r } & . & . \\ . & . & . & \text { I } & \text { r } & \text { I } & . & + & . & .\end{array}$

D.s. of Festuco-Brometea class

$\begin{array}{llllllllll}\text { III } & \text { II } & \text { III } & \text { IV } & \text { II } & \text { IV } & \text { II } & \text { II } & \text { V'-3 } & \text { V } \\ \text { I } & \text { r } & \text { I } & \text { I } & \text { r } & \text { III } & \text { III } & \text { I } & \text { III } & \text { V } \\ \text { I } & r & \text {. } & \text { III } & \text { I } & \text {. } & \text { II } & \text { II } & \text { IV } & \text { IV }\end{array}$

Onobrychis arenaria

Veronica spicata

Adonis vernalis

Dracocephalum thymiflorum

Crepis tectorum

Agrimonia pilosa

Veronica chamaedrys

Origanum vulgare

Hypericum perforatum

Anthemis tinctoria

Convolvulus arvensis

Chenopodium album

Conyza canadensis

Matricaria recutita

Sisymbrium loeselii

Lathyrus tuberosus

Pastinaca sy/vestris

Cirsium arvense
IV

II

II

$\begin{array}{lll}\text { II } & \cdot & \cdot \\ r & \text { III } & \text { I } \\ \cdot & \text { II } & \text { II } \\ r & \text { I } & \text { III }\end{array}$

D.s. of Trifolio-Geranietea class

$\begin{array}{llllllllll}\text { II } & \text { II } & \text { III } & \text { II } & \text { r } & \text { I } & \text { II } & \text { III } & \text { r } & + \\ . & + & + & \text { II } & \text { II } & \text { IV } & \text { II } & + & \text { II } & \text { II } \\ \text { II } & \text { II } & . & . & \text { IV } & . & \text { II } & \text { II } & \text { r } & + \\ . & \text { I } & . & . & \text { r } & \text { I } & . & . & + & + \\ \text { I } & \text { I } & . & . & \text { IV } & \text { I } & \text { III } & \text { III } & + & \text { I } \\ . & \text {. } & . & . & \text { II } & . & . & \text { r } & . & .\end{array}$

D.s. of Stellarietea media class

$\begin{array}{llllllllll}\text { V } & \text { IV } & \text { III } & \text { V } & \text { III } & \text { II } & \text { IV } & \text { V } & \text { II } & \text { I } \\ \text { II } & . & . & + & . & . & . & \text { r } & \text { I } & \text {. } \\ \text {. } & \text { I } & \text { I } & \text { I } & \text { r } & \text { III } & . & . & . & \text {. } \\ \text {. } & + & . & . & . & \text { IV } & . & \text { r } & . & \text {. } \\ \text { II } & \text {. } & \text { I } & + & . & . & . & . & . & \text {. } \\ \text { I } & \text { IV } & \text { II } & + & . & . & . & . & . & \text {. } \\ \text { I } & \text {. } & . & + & . & . & . & + & . & \end{array}$.


Berteroa incana

D.s. of Artemisietea vulgaris class

Potentilla argentea

Artemisia sieversiana

Achillea asiatica

Linaria vulgaris

Echium vulgare

Urtica dioica

Melandrium album

Cichorium intybus

Picris hieracioides

Nonea rossica

Melilotus officinalis

Bunias orientalis

Carduus crispus

Melilotus albus

Taraxacum officinale

Amoria repens

\begin{tabular}{|c|c|c|c|c|c|}
\hline II & V & IV & V & III & $\mathrm{V}$ \\
\hline IV & V & V & IV & III & V \\
\hline I & III & III & II & I & III \\
\hline I & I & II & III & IV & V \\
\hline II & III & II & II & III & IV \\
\hline . & III & III & I & IV & III \\
\hline . & + & II & . & . & . \\
\hline III & I & . & . & $r$ & . \\
\hline II & I & . & II & I & . \\
\hline . & . & . & + & . & . \\
\hline II & $r$ & . & III & + & . \\
\hline I & . & . & II & $r$ & . \\
\hline II & . & + & II & . & . \\
\hline . & $r$ & + & II & . & . \\
\hline I & . & . & + & . & . \\
\hline
\end{tabular}

D.s. of Polygono arenastri-Poetea annuae class

Plantago major

III

II

I III

III II

II

v

III
V
III
II
+
V

$\begin{array}{lll}\text { V } & \text { V } & \text { III } \\ \text { III } & \text { V } & \text { II } \\ \cdot & \text { II } & + \\ \text { II } & \text { I } & \text { II } \\ \text { III } & \cdot & + \\ \text { IV } & \text { IV } & \text { III }\end{array}$

.

I II

I II

(1)

$r$

II $\quad r$

-

Note. D.s. - diagnostic species, highlighted with colour. Use: IL - idle land, P - pasture, H - hayfield. Syntaxons: 1 - community Bromopsis inermis, 2 - community Agrostis stolonifera; 3 - community Poa pratensis, 4 - community Poa angustifolia; 5 - community Agrostis tenuis, 6 - community Elytrigia repens; 7 - community Agrostis clavata; 8 - association Festuco pratensis-Dactyletum glomeratae, 9 - community Nonea pulla-Poa angustifolia; 10 - community Vicia amoena-Poa angustifolia.

\section{MOLINIO-ARRHENATHERETEA ClasS}

Diagnostic species: Achillea millefolium, Agrostis gigantea, Bromopsis inermis, Carum carvi, Dactylis glomerata, Elytrigia repens, Festuca pratensis, Geranium pratense, Lathyrus pratensis, Leucanthemum vulgare, Phleum pratense, Plantago media, Poa pratensis, Ranunculus polyanthemos, Stellaria graminea, Trifolium pratense, Vicia cracca.

The Molinio-Arrhenatheretea class encompasses secondary post-forest meadows of the Eurasia temperate zone on relatively rich non-saline soils. Communities are formed as a result of deforestation (broad-leaved, mixed, coniferous forests) with a subsequent mowing or grazing use of the territory. For this reason, the basis of the grassstand is comprised of species adapted to restore phytomass after regular disposal - mowing or grazing.

The range of the class covers the whole of Western, Central and Eastern Europe, most of Russia from the western borders to the Far East (Tüxen, Preising, 1951; Dierschke, 1995, 1997; Schaminee et al., 1996 Ermakov et al., 1999; Matuszkiewicz, 1984; Mucina et al., 1993; Korolyuk, Kipriyanova, 1998; Rodwell et al., 2007; Janišova et al., 2007; Vegetace..., 2007; Korolyuk, Makunina, 2000, 2001; Makunina, Maltseva, 2003; Lashinskiy, 2009; Averinova, 2010; Yamalov, 2011, etc.). The class communities are well represented in the Transbaikal and Yakutia regions. In the south of the Far East, it is replaced by the East Siberian Far Eastern vicariant classes Calamagrostietea langsdorffii Mirkin in Akhtyamov et al. 1985 (Akhtyamov, 1995; 2000; Anenkhonov, 2003) and Arundinello anomalae - Agrostietea trinii Ermakov et Krestov 2009 (Ermakov, Krestov, 2009).

In the territory under study, the class is represented by three orders Molinietalia, Arrhenatheretalia, Galietalia veri, which comprise wet, real and steppe meadows respectively.

\section{MOLINIETALIA Koch 1926 order}

Diagnostic species: Agrostis stolonifera, Potentilla anserina.

The order comprises wet meadows, which floristic composition is characterised by the dominance of water resistant species. On the gradient of environmental conditions, on one side, they border on the well-hydrated meadows of the Arrhenatheretalia order, and on the communities of eutrophic high sedge and grass bogs of the Magnocaricetalia order (Phragmiti-Magnocaricetea class) on the other side. Only one community of meadows is assigned to this order in the Potentillion anserinae alliance system.

Potentillion anserinae R. Tx. 1947 alliance

It unites the communities of plants resistant to grazing and trampling, growing on waterlogged soils in the conditions of intensive grazing. It is formed in depressions along the banks of ponds, rivers, and streams on annually flooded habitats (Passarge 1964; Ellmauer, Mucina, 1993; Vegatace.., 2007; Grigoryev et al., 2002; Cherosov et al., 2005).

Diagnostic species: Agrostis stolonifera.

\section{Agrostis stolonifera community}

It comprises communities with intensive grazing use. They are common for low habitats with moderate soil moistening in the Kosikhinskiy district.

The projective cover of the grassstand varies from 55 to $75 \%$. Despite the anthropogenic load, the species range of the communities remains rather high and averages 19 species per $100 \mathrm{~m}^{2}$. The height of the grassstand is $65 \mathrm{~cm}$ on average. 
The group of the Molinio-Arrhenatheretea class meadow species (Dactylis glomerata, Stellaria graminea, Trifolium pratense, Phleum pratense) is encountered with high constancy. The proportion of species of the Trifolio-Geranietea class forest edge and woodland communities (Agrimonia pilosa, Hypericum perforatum, Origanum vulgare, Veronica chamaedrys) is not high. A noticeable part of the grass stand is a group of synanthropic herbaceous species of the Artemisietea vulgaris class (Berteroa incana, Echium vulgare, Arctium tomentosum, Artemisia sieversiana, etc.). A significant role in the floristic composition belongs to species of the Polygono arenastri-Poetea annuae class that withstand trampling and high pasture load - Amoria repens, Taraxacum officinale. When trampling is reduced or stopped, meadow species of the Molinio-Arrhenatheretea class insinuate into the community. It differs from other communities in a more mesophytic composition and a higher proportion of meadow species, which indicates the formation of natural vegetation, but pasture load blocks restoration.

\section{ARRHENATHERETALIA order}

Diagnostic species of the order $=$ diagnostic species of the class.

The order is characteristic of the well-hydrated meadows in the temperate zone of Eurasia. The grass stand is based on typical mesophytes that participate in the class communities. Habitats are most often characterized by rich soils and moderate moistening. On the gradient of humidification, as the leading differentiating factor of the Molinio-Arrhenatheretea class meadows, communities of the Arrhenatheretalia order border on the wet meadows of the Molinietalia order on the one side and on the steppe meadows of the Galietalia veri order on the other side.

In the classification by dominants traditional for Soviet geobotany, the order corresponds in its volume to the class of "true" meadow formations that were the object for many researchers of meadow vegetation in the USSR (Shennikov, 1923, 1938; Alekhin, 1925; Balandin, 1929; Nitsenko, 1955; Nomokonov, 1959, 1962; Sabardina, 1957, etc.).

Mesophytes that are included in the diagnostic combination of the Molinio-Arrhenatheretea class - Achillea millefolium, Dactylis glomerata, Elytrigia repens, Phleum pratense, Poa pratensis, Ranunculus polyanthemos, Trifolium pratense, Vicia cracca, etc. dominate in the floristic composition of the order communities.

In the studied area, all the communities of the order are assigned to the central Festucion pratensis alliance.

Festucion pratensis Sipajlova et al. 1985 alliance

Diagnostic species of the alliance $=$ diagnostic species of the order.

The alliance is typical for hayfields or mowing and grazing communities with a low pasture load. The grass stand is dominated by grasses Agrostis gigantea, Alopecurus pratensis, Bromopsis inermis, Dactylis glomerata, Festuca pratensis, Phleum pratensis, Poa pratensis. Besides, such herbs as Geranium pratense, Lathyrus pratensis, Leucanthemum vulgare, Vicia cracca actively participate in the composition of the alliance communities. It includes the most typical communities of the Molinio-Arrhenatheretea class. In the conditions of forest and forest-steppe zones, the communities occupy upland and floodplain habitats.

According to the Soviet classification by dominants, tall grass meadows formation group include the following formations: bromegrass, bromegrass-quackgrass meadows, foxtail and red-tailed fescue meadows (Shennikov, 1938). Associations of this alliance, determined by the Braun-Blanquet method, basically coincide in volume with the formations listed.

The alliance was first described in Ukraine (Sipaylova et al., 1985). According to its initial interpretation, it unites meadow communities on rich soils in Eastern Europe and Siberia and is a vicariant of the Arrhenatherion elatioris Luquet 1926 alliance in Western Europe (Balevičienè et al., 1998; Bulokhov, 2001; Kuzyarin, 2008; Bulokhov, Kharin, 2008; Kuzemko, 2009; Averinova, 2010).

The alliance includes 4 communities and one association.

Diagnostic species: Bromopsis inermis.

\section{Bromopsis inermis community}

The community encompasses meadows common for upland habitats with moderate soil moistening. They are spread throughout the Biysk-Chumysh Upland (within the territory of Altai Krai). These communities are caracterised by a haying mode of use.

The projective cover of the grass stand varies from 60 to $100 \%$. The number of species per $100 \mathrm{~m}^{2}$ averages 22 (from 19 to 31 species). The height of the grass stand is $65 \mathrm{~cm}$ on average.

The community is characterized by a constant dominance of Bromopsis inermis and active participation of the MolinioArrhenatheretea class (Dactylis glomerata, Vicia cracca, Festuca pratensis, Stellaria graminea, Trifolium pratense), FestucoBrometea class (Onobrychis arenaria, Medicago falcata) species. The participation of synanthropic species is not significant: only Potentilla argentea and Convolvulus arvensis are frequently encountered.

The Brometum inermis is distinguished from the close communities of the Convolvulo arvensis association by a larger range of species, a smaller proportion of synanthropic species and a higher proportion of meadow ones.

Diagnostic species: Poa pratensis.

\section{Poa pratensis community}

The community comprises meadows common for upland habitats with moderate soil moistening. They are spread in Kosikhinsky and Zonalniy districts. It unites the communities used as pasture, less often as hayfields with irregular mowing mode. The boundaries between the communities of mowing and grazing use are fuzzy. The communities easily transform into each other when the mode of use is changed.

The projective cover of the grass stand varies from 60 to $75 \%$. The number of species per $100 \mathrm{~m}^{2}$ averages 16 . The height of the grass stand is $55 \mathrm{~cm}$ on average.

A group of meadow species of the Molinio-Arrhenatheretea class (Phleum pratense, Vicia cracca, Achillea millefolium, Galium boreale, Bromopsis inermis, etc.) is highly constant. A noticeable part of the grass stand is a group of meadow steppe species of the Festuco-Brometea class (Medicago falcata, Poa angustifolia, Onobrychis arenaria). The short grass group is represented by Amoria repens, Taraxacum officinale, Poa pratensis.

The community is closest to the Poa angustifolia one, however differs from it in its floristic composition which is less xerophytic due to less drained habitats 


\section{Agrostis tenuis community}

Diagnostic species: Agrostis tenuis, Lotus ucrainicus, Pimpinella saxifraga, Plantago lanceolata, Trifolium arvense.

The community comprises meadows spread in upland habitats with moderate soil moistening. They are described in Troitskiy and Kosikhinskiy districts in the more depressed areas and are used as pastures.

The average number of species on the site is 21 . The average height of the grass stand is $55 \mathrm{~cm}$. The projective cover of the grass stand varies from 70 to $100 \%$.

A group of meadow species of the Molinio-Arrhenatheretea class (Poa pratensis, Pimpinella saxifraga, Stellaria graminea, Trifolium pratense, Vicia cracca, Achillea asiatica, etc.) and pasture species of the Polygono arenastri-Poetea annuae class (Amoria repens, Taraxacum officinale) are highly constant in the floristic composition. The proportion of synanthropic biennial and perennial species of the Artemisietea vulgaris class remains significant in the composition of the grass stand (Echium vulgare, Artemisia absinthium, Berteroa incana, Linaria vulgaris, etc.).

It differs from other idle land communities in a relatively low proportion of annual and biennial weeds, representing the initial stages of progressive successions after the disturbances of the Stellarietea mediae class as well as in an increase in the proportion of meadow species of the Molinio-Arrhenatheretea class and species of forest edges and woodlands of Trifolio-Geranietea (Hypericum perforatum, Veronica chamaedrys, Agrimonia pilosa and others).

Diagnostic species: Agrostis clavata, Amoria hybrida.

\section{Agrostis clavata community}

The community encompasses meadows formed in the conditions of normal and excessive moistening, confined to more acidic soils. They are described in Kosikhinskiy district and are used as pastures.

The average number of species on the site is 18 . The average height of the grass stand is $60 \mathrm{~cm}$. The projective cover of the grass stand varies from 70 to $90 \%$.

A group of meadow species of the Molinio-Arrhenatheretea class (Dactylis glomerata, Stellaria graminea, Poa pratensis, Bromopsis inermis, Galium mollugo, Leucanthemum vulgare, Phleum pratense) is highly constant. The synanthropic fraction of cenoflora includes species of the Artemisietea vulgaris and Stellarietea mediae classes (Echium vulgare, Potentilla argentea, Berteroa incana, Convolvulus arvensis, Artemisia sieversiana). Pasture species of the Polygono arenastri-Poetea annuae class are encountered with low constancy and abundance.

It differs from other communities by a more mesophytic composition of species of the Molinio-Arrhenatheretea class, which is associated with the specificity of more hydrated habitats.

\section{Festuco pratensis-Dactyletum glomeratae Dymina in Maltseva et Macunina 2008 association} Diagnostic species: Dactylis glomerata.

The community comprises dry meadows, spread in the conditions of sufficient moistening in all areas of the Biysk-Chumysh Upland (Altai Territory). They are located on meadow and meadow chernozem soils on smooth slopes. The mode of use is haying.

The projective cover of the grass stand varies from 70 to $100 \%$. The number of species per $100 \mathrm{~m}^{2}$ averages 29 . The height of the grass stand is $65-70 \mathrm{~cm}$ on average.

Besides cocksfoot - Dactylis glomerata, other grasses, mainly rootstock loose-bunch grasses (Poa pratensis, Festuca pratensis, Phleum pratense) take a significant part in the formation of the grass cover. A group of meadow species of the MolinioArrhenatheretea class (Agrostis tenuis, Galium mollugo, Phleum pratense, Trifolium pratense, Leucanthemum vulgare) is highly constant. A notable part of the stand is composed of synanthropic species of the Stellarietea mediae class (Berteroa incana, Convolvulus arvensis, Echium vulgare, etc.).

It differs from other studied communities by the predominance of meadow grasses. The association has a wide range in Siberia, its communities are widespread in the subtaiga and forest steppe regions of the Ob-Yenisei interfluve, the subtaiga forest steppe belt of Salair, Kuznetsk Alatau, Western and Eastern Sayan (Dymina, 1989; Makunina, Maltseva, 2003).

GALIETALIA VERI Mirk. et Naumova 1986 order

Diagnostic species: Amoria montana, Astragalus danicus, Centaurea scabiosa, Filipendula vulgaris, Fragaria viridis, Galium verum, Medicago falcata, Phleum phleoides, Phlomoides tuberosa, Poa angustifolia, Rosa majalis, Seseli libanotis, Stipa pennata, Thalictrum minus, Veronica spicata.

The order unites the communities, cenoflora of which combines species of true meadows and meadow steppes, that is usually called steppe meadows in the literature (Shennikov, 1938). The climate changing, steppe meadows transform into meadow steppes. Thus, steppe meadows are ecotones between true meadows and meadow steppes.

A specific feature of the communities in this order is the simultaneous growth of typically meadow species of the MolinioArrhenatheretea class and the Arrhenatheretalia order (Achillea millefolium, Bromopsis inermis, Elytrigia repens, Festuca pratensis, Geranium pratense, Lathyrus pratensis, Trifolium pratense, Vicia cracca, etc.) together with meadow steppe species of the Festuco-Brometea Br.-Bl. et Tx. 1943 class (Amoria montana, Centaurea scabiosa, Filipendula vulgaris, Festuca pseudovina, Galium verum, Poa angustifolia, Phleum phleoides, Phlomoides tuberosa, Medicago falcata, etc.).

On the humidification gradient, communities of the order border on well-hydrated meadows of the Arrhenatheretalia order on one side and on the communities of the Festuco-Brometea class, uniting xerothermic and hemixerothermic steppe communities on the other side. The diagnostic combination of the Galietalia veri order consists mainly of steppe and meadow steppe species, which are also used to diagnose the Festuco-Brometea class (and its more mesophytic wing - the Festucetalia valesiacea order), which, in this case, act as differentiating species, separating the Galietalia veri steppe meadows from meadows of the Arrhenatheretalia order. Communities of the Galietalia veri order are distinguished from typical steppe communities of the Festuco-Brometea class by the presence of mesophilic meadow species of the Molinio-Arrhenatheretea class.

The communities we studied are classified as part of the central Trifolion montani alliance.

Trifolion montani Naumova 1986 alliance

Diagnostic species of the alliance $=$ Diagnostic species of the order

It is the central alliance of the order, comprising its most typical communities.

The alliance includes 4 communities. 
Diagnostic species: Poa angustifolia.

\section{Poa angustifolia community}

The community encompasses steppe meadows, widespread in the conditions of insufficient moistening in all areas of the BiyskChumysh Upland (within the territory of Altai Krai). Habitats are located on elevated relief features. They are used as pastures.

The projective cover of the grass stand varies from 50 to $90 \%$. The number of species per $100 \mathrm{~m}^{2}$ averages 20 . The height of the grass stand is $55 \mathrm{~cm}$ on average.

The physiognomy of the community is determined by the dominance of the narrow-leaved bluegrass - Poa angustifolia. A group of meadow mesophytes of the Molinio-Arrhenatheretea class (Bromopsis inermis, Achillea asiatica, Trifolium pratense) is highly constant and abundant. A significant proportion of the grass stand is composed of the group of meadow-steppe species of the Festuco-Brometea class (Medicago falcata, Galium verum, Centaurea scabiosa, etc.). Synanthropic species of the Artemisietea vulgaris class (Berteroa incana, Potentilla argentea, Nonea rossica) are encountered with relatively high constancy (III-V points). It differs from the close Poa pratensis community by a more xerophytic floristic composition due to more drained habitats.

\section{Elytrigia repens community}

Diagnostic species: Elytrigia repens, Festuca pseudovina.

It encompasses steppe meadows, which physiognomy is determined by the dominance of the Eurasian species Elytrigia repens. They are common for abandoned arable lands, on the edges of fields, along field roads, near villages in Kosikhinskiy district. The community use is grazing.

The projective cover of the grass stand varies from 55 to $70 \%$. The number of species per $100 \mathrm{~m}^{2}$ averages 16 . The height of the grass stand is $45 \mathrm{~cm}$ on average.

Meadow species of the Molinio-Arrhenatheretea class (Galium mollugo, Trifolium pratense, Poa pratensis, etc.) participate in the composition of the grass stand. A group of ruderal species of the Artemisietea vulgaris class (Achillea asiatica, Berteroa incana, Potentilla argentea, Linaria vulgaris) is active. Meadow-steppe species of the Galietalia veri, Festuco-Brometea order (Medicago falcata, Centaurea scabiosa, Vicia amoena) are highly constant. A significant part of the grass stand is composed of synanthropic species of the Stellarietea mediae class (Matricaria recutita, Conyza canadensis, Convolvulus arvensis), Artemisietea vulgaris class (Berteroa incana, Achillea asiatica, Echium vulgare, etc.). Amoria repens resistant to trampling and grazing is rather frequent. The share of apophytes is high.

The community is an advanced stage of a progresssive succession of vegetation. It is close to associations of idle lands of Western and Eastern Convolvulo arvensis-Elytrigietum repentis Felföldy 1943 (Arepieva, 2012) and Pastinaco sy/vestrisElytrigietum repentis Ishbirdin in Ishbirdin et al. 1988. However, the communities that we described differ from them by a higher constancy of meadow species of the Molinio-Arrhenatheretea class in the floristic composition, as well as by the presence of Festuca pseudovina in the cenoflora.

\section{Diagnostic species: Poa angustifolia, Nonea pulla.}

The community comprises steppe meadows, common in the conditions of insufficient moistening in Kosikhinskiy district. Communities are not used; in rare cases, limited grazing is observed.

The projective cover of the grass stand varies from 60 to $100 \%$. The number of species per $100 \mathrm{~m}^{2}$ averages 22 . The height of the grass stand is $50 \mathrm{~cm}$ on average.

The core of the floristic composition is composed of meadow steppe species of the Galietalia veri order and Festuco-Brometea class (Medicago falcata, Scabiosa ochroleuca, Phleum phleoides, Centaurea scabiosa, Galium verum). Meadow mesophytes of the Molinio-Arrhenatheretea class are less represented, only Poa pratensis and Vicia cracca have constancy class III.

A noticeable part of the grass stand is composed of species of the Artemisietea vulgaris and Stellarietea mediae classes (Nonea pulla, Berteroa incana, Potentilla argentea, Echium vulgare, Achillea millefolium, Convolvulus arvensis).

They differ from other communities by a more xerophytic composition.

Diagnostic species: Poa angustifolia, Vicia amoena, Filipendula vulgaris, Fragaria viridis, Phlomoides tuberosa, Trommsdorfia maculata.

The community comprises steppe meadows widespread in the conditions of insufficient moisture in Tselinniy, Kosikhinskiy districts. The territory is not used at all or limited grazing is observed.

The projective cover of the grass stand varies from 70 to $100 \%$. The number of species per $100 \mathrm{~m}^{2}$ averages 22 . The height of the grass stand is $50 \mathrm{~cm}$ on average.

A group of meadow steppe species of the Festucetalia valesiace order, Festuco-Brometea class (Centaurea scabiosa, Medicago falcata, Scabiosa ochroleuca, Galium verum, Phleum phleoides) is highly constant. Meadow species of the MolinioArrhenatheretea class (Rumex acetosa, Dactylis glomerata, Elytrigia repens, Leucanthemum vulgare, Plantago media, etc.) and species of the Artemisietea vulgaris class (Dracocephalum thymiflorum, Echium vulgare, etc.) take a significant share in the grass stand.

It differs from other communities by the predominance of steppe and meadow steppe species and represents the most advanced stage towards the formation of meadow steppes of the Festuco-Brometea class.

\section{Conclusion}

The meadow phytocenoses of the Molinio-Arrhenatheretea class are represented by three orders (Molinietalia, Arrhenatheretalia, Galietalia veri), which comprise wet, true and steppe meadows, respectively. The syntaxonomic analysis of the studied area revealed 1 association, 9 rankless communities, which are characterized by leading environmental factors (humidification gradient) and the level of use (grazing, haying, idle land).

The Molinietalia order encompasses wet meadows, which are mostly formed in the northern part of the Biysk-Chumysh Upland, in the floristic composition of which water-resistant species predominate. Only one community of meadows (the Agrostis stolonifera community) is assigned to this order in the Potentillion anserinae alliance system. The Potentillion anserinae alliance unites the 
communities that are resistant to grazing, trampling of plants growing on waterlogged soils in the conditions of intensive grazing. It is encountered in depressions along the banks of ponds, rivers and streams. The Arrhenatheretalia order comprises well-hydrated meadows. The core of the grass stand is composed of typical mesophytes that participate in the communities of the class. Habitats are most often characterized by rich soils and moderate moistening. In the studied area, all the order communities are assigned to the central Festucion pratensis alliance. The alliance unites hayfields, or mowing and grazing communities with a low pasture load. The communities of this alliance occupy the upland and flood plain habitats of the Biysk-Chumysh Upland.

The Galietalia veri order encompasses the communities which cenoflora comprises species of true meadows and meadow steppes. A specific feature of this order communities is the simultaneous growth of typically meadow species of the Molinio-Arrhenatheretea class and the Arrhenatheretalia order and meadow steppe species of the Festuco-Brometea class.

\section{References}

Akhtyamov, M.Kh. (1995). Sintaksonomiya lugovoy rastitelnosti basseyna reki Amur. Vladivostok; Khabarovsk.

Akhtyamov, M.Kh. (2000).Sintaksonomiya rastitelnosti poymy reki Amur. Vladivostok.

Alekhin, V.V. (1925). Nashi poymennyye luga. Moscow.

Aleksandrova, V.D., Guricheva, N.P., Ivanina, L.I. (1958). Rastitelnyy pokrov i prirodnyye kormovyye ugodya Altayskogo kraya. Prirodnoye rayonirovaniye Altayskogo kraya. Moscow: Academy of Science of USSR.

Anenkhonov, O.A. (2003). Sintaksonomiya soyuza Caricion appendiculatae Akhtymov et al. 1985 (Calamagrostietea langsdorfii) v Severnom Zabaykalye. Rastitelnost Rossii, 5, 3-18.

Arepyeva, L.A. (2012). O soobshchestvakh pozdnikh suktsessionnykh stadiy ruderalnoy rastitelnosti na urbanizirovannykh territoriyakh Kurskoy oblasti. Rastitelnost Rossii, 21, 13-24.

Averinova, Ye.A. (2010). Travyanaya rastitelnost basseyna reki Seym (v predelakh Kurskoy oblasti). Bryansk.

Balandin, F.V. (1929).Senokosy Leningradskoy oblasti i Karelii. Izv. po s.-kh. opytn. delu Leningradskoy oblasti.

Balevičiene, J., Kiziene, B., Lazdauskaite, Ž., Patalauskaite, D., Rašomavičius, V., Sinkeviciene, Z., Tučiene, A., Venckus, Z. Lietuvos Augalija I. Pievos. (1998). Vegetation of Lithuania. Grasslands. Šviesa. Kaunas, Vilnius.

Bazilevich, N.I., Shavrygin, P.I. (1959). Intrazonalnyye pochvennyye rayony Altayskikh ravnin. Pochvy Altayskogo kraya. Moscow: Academy of Science of USSR.

Bulokhov, A.D. (2001). Travyanaya rastitelnost yugo-zapadnogo Nechernozemya Rossii. Bryansk. Bryansk State University.

Bulokhov, A.D., Kharin, A.V. (2008). Rastitelnyy pokrov goroda Bryanska i yego prigorodnoy zony. Bryansk. Bryansk State University.

Cherosov, M.M., Sleptsova, N.P., Mironova, S.I., Gogoleva, P.A., Pestryakov, B.N., Gavrilyeva, L.D. (2005). Sintaksonomiya sinantropnoy rastitelnosti Yakutii. Yakutsk: Siberian Branch Russian Academy of Science.

Dierschke, H. (1994). Pflanzensociogie. Stuttgart: Ulmer.

Dierschke, H. (1995). Syntaxonomical survey of Molinio-Arrhenatheretea in Central Europe. Colloques Phytosociologiques, XXIII, Large are vegetation surveys. Berlin, Stuttgart.

Dymina, G.D. (1989). Klassifikatsiya, dinamika i ontogenez travyanykh fitotsenozov (na primere regionov Sibiri i Dalnego Vostoka). Novosibirsk.

Ellmauer, T., Mucina, L. (1993). Molinio-Arrhenatheretea. In: Mucina L., Grabherr G., Ellmauer T. (Hrsg.) Die Pflanzengesellschaften Osterreichs. Teil 1. Antropogene Vegetation. Jena-Stuttgart-New-York: Gustav Fischer Verlag, 297-401.

Ermakov, N., Maltseva, T., Macunina, N. (1999). Classification of the meadows of the South Siberian uplands and mountains. Folia geobotanica, 34, 221-242.

Grigoryev, I.N., Solomeshch, A.I., Alimbekova, L.M., Onishchenko, L.I. (2002). Vlazhnyye luga Respubliki Bashkortostan: sintaksonomiya i voprosy okhrany. Ufa.

Hennekens, S. M. (1996). TURBO(VEG). Software package for input, processing, and presentation of phytosociological data. User's guide. Lancaster.

Janišová, M., Hájková, P., Hegedüšová, K., Hrivnák, R., Kliment, J., Michálková, D., Ružičková, H., Řezníčková, M., Tichý, L., Škodová, I., Uhliarová, T., Ujházy, K., Zaliberová, V. (2007). Travinnobylinná vegetácia Slovenska - electronicý expertný system na identifikáciu syntaxónov. Botanický ústav SAV, Bratislava.

Korolyuk, A.Yu., Kipriyanova, L.M. (1998). Prodromus yestestvennoy rastitelnosti yugo-vostoka Zapadnoy Sibiri (Altayskiy kray i Novosibirskaya oblast). Botan. issledovaniya Sibiri i Kazakhstana. Sbornik nauchnykh statey gerbariya im. V.V.Sapozhnikova. Barnaul, 4, 63-89.

Korolyuk, A.Yu., Makunina, N.I. (2000). Lugovyye stepi Altaye-Sayanskoy gornoy oblasti. Obshchaya kharakteristika. Krylovia, 2(1), 26-37.

Korolyuk, A.Yu., Makunina, N.I. (2001). Lugovyye stepi Altaye-Sayanskoy gornoy oblasti. Poryadok Stipetalia sibiricae, soyuz Aconito barbate-Poion transbaicalicae. Krylovia, 3(2), 35-49.

Kravtsova, V.I. (1959). Stroyeniye relyefa i yego znacheniye dlya selskogo khozyaystva Altayskogo kraya. Pochvy Altayskogo kraya. Moscow. Academy of Science of the USSR.

Kuminova, A.V., Vagina, T.A., Lapshina, Ye.I. (1963). Geobotanicheskoye rayonirovaniye yugo-vostoka Zapadno-Sibirskoy nizmennosti. Rastitelnost stepnoy i lesostepnoy zon Zapadnoy Sibiri. Novosibirsk: Siberian Branch Academy of Science of the USSR.

Kuzemko, A.A. (2009). Luchna roslinnist. Klass Molinio-Arrhenatheretea. Yu.R. Shelyag-Sosonko (Ed.). Roslinnist Ukraíni. Kiev: Fitosotsiotsetr.

Kuzyarin, A.T. (2008). Poymennaya rastitelnost basseyna verkhovyev Zapadnogo Buga: ekologo-tsenoticheskaya struktura, dinamicheskiye tendentsii, okhrana. Kiev.

Lashchinskiy, N.N. (2009). Rastitelnost Salairskogo kryazha. Novosibirsk: Geo.

Makunina, N.I., Korolyuk, A.Yu., Maltseva, T.V. (2010). Rastitelnost Biysko-Chumyshskoy vozvyshennosti. Rastitelnost Rossii, 16, 40-55.

Makunina, N.I., Maltseva, T.V. (2003). Luga lesnogo poyasa vostochnogo makrosklona Kuznetskogo Alatau. Rastitelnost Rossii, SPb., 4, 51-61.

Matuszkiewicz, W. (1984). Przewodnik do oznaczania zbiorowisk roslinnych Polski. Warszawa.

Mirkin, B.M., Naumova, L.G., Solomeshch, A.I. (2001). Sovremennaya nauka o rastitelnosti. Moscow. Logos 
Mucina, L., Grabherr, G., Ellmauer, T. (1993). Die Pflanzengesellschaften Österreichs. Teil I. Anthropogene vegetation. Jena; Stuttgart; New York: Gustav Fisher Verlag.

Nitsenko, A.A. (1955). Luga Leningradskoy oblasti i mery ikh uluchsheniya. Vestnik LGU. Ser. biol., geogr. i geol., 4, 3-14.

Nomokonov, L.I. (1962). Poymennyye luga verkhnego techeniya reki Leny. Moscow.

Nomokonov, L.I. (1959). Poymennyye luga Yeniseya. Leningrad. Nauka.

Omelyanov, V.P. (1973). Osobennosti raspredeleniya vlazhnosti pochvy raspakhannykh sklonov yugo-zapadnoy chasti BiyeChumyshskoy vozvyshennosti. Pochvennaya klimatologiya Sibiri.edt. Slyadnev A.P. Novosibirsk: Nauka, Sibirskoye otdeleniye.

Ovcharova, N.V., Yamalov, S.M. (2013). Sintaksonomicheskiy i ordinatsionnyy analizy vosstanovitelnykh suktsessiy travyanoy rastitelnosti pravoberezhya reki Obi (Altayskiy kray). Izvestiya Samarskogo nauchnogo tsentra Rossiyskoy akademii nauk. Samara.

Passarge, H. (1964). Pflanzengesellschaften des nordostdeutschen Flachlandes I. Pflanzensoziologie, 13, 1-324.

Polyakov, P.P. (1934). Materialy Kuznetsko-Barnaulskoy pochvennoy ekspeditsii 1931. Botaniko-geograficheskiye ocherki Kuznetskoy kotloviny, Salaira i zapadnoy Predsalairskoy polosy. Leningrad.

Rodwell, J.S., Morgan, V., Jefferson, R.G., Moss, D. (2007). The European context of British Lowland Grasslands. JNCC Report, 394. Ronginskaya, A.V. (1963). Stepi yugo-vostoka Zapadno-Sibirskoy nizmennosti. Rastitelnost stepnoy i lesostepnoy zon Zapadnoy Sibiri. Novosibirsk. Siberina Branch Academy of Science of the USSR.

Rozanov, A.N. (1959). Osnovnyye printsipy pochvenno-geograficheskogo rayonirovaniya Altayskogo kraya. Pochvy Altayskogo kraya. Moscow. Izd-vo Academy of Science of the USSR.

Sabardina, G.S. (1957). Lugovaya rastitelnost Latviyskoy SSR. Riga: Academy of Science of Latvian SSR.

Schaminee, J.H., Stortelder, A., Weeda, E.J. (1996). De vegetatie van Nederland. Deel 3. Plantengemeenschappen van graslanden, zomen en droge heiden. Uppsala: Opulus press.

Shennikov, A.P. (1923). Luga Simbirskoy gubernii. Trudy Bezenchukskoy oblastnoy selskokhozyaystvennoy opytnoy stantsii, 2(103), 69.

Shennikov, A.P. (1938). Lugovaya rastitelnost USSR . Rastitelnost USSR. V. 1. Moscow. Leningrad.

Sipaylova, L.M., Mirkin, B.M., Shelyag-Sosonko, Yu.R., Solomakha, V.A. (1985). Novi soyuzi Agrostion vinealis ta Festucion pratensis luchnoi roslinnosti. Ukr. bot. zhurn., 42(4), 13-18.

Sokolova, G.G. (2002). Rastitelnost stepnoy i lesostepnoy zon Altayskogo kraya: monografiya. Barnaul: Altai State University.

Tichý, L. (2002). JUICE, software for vegetation classification. J. Veg. Sci., 13, 453.

Tüxen, R., Preising, E. (1951). Erfahrungsgrundlagen fur die pflanzensoziologische Kartierung des westdeutschen Grünlandes. Angewandte Pflanzensoziologie. Stolzenau, Weser, 4, 5-28.

Vegetace České republiky. (2007). 1. Travinná a keř́čcková vegetace (Vegetation of the Czech Republic. 1. Grassland and heathland vegetation) / Milan Chytrý (editor) a kolektiv. Vyd. 1. Praha: Academia.

Weber, H.E., Moravec, J., Theurillat, J. (2000). Internetional Code of Phytosociological Nomenclature. J. Veg. Sci., 11(5), 739-768.

Westhoff, V., van der Maarel, E. (1973). The Braun-Blanquet Approach. Handbook of Vegetation Science. P.S. Ordination and classifi cation of communities. The Hague.

Yamalov, S.M. (2011). Sintaksonomiya i dinamika travyanoy rastitelnosti Yuzhno-Uralskogo regiona. Ufa.

Yermakov, N.B. (2012). Prodromus vysshikh yedinits rastitelnosti Rossii. Sovremennoye sostoyaniye osnovnykh kontseptsiy nauki o rastitelnosti. Ufa, Gilem.

Yermakov, N.B., Krestov, P.V. (2009). Reviziya vysshikh yedinits lugovoy rastitelnosti yuga Dalnego Vostoka. Rastitelnost Rossii, 14, $37-48$.

Zyatkova, L.K. (1977). Biysko-Barnaulskaya vpadina. Strukturnaya geomorfologiya Altaye-Sayanskoy gornoy oblasti. Novosibirsk.

\section{Citation:}

Ovcharova, N.V., Matsyura, A.V. (2020). Communities of the Molinio-Arrhenatheretea class in the Biysk-Chumysh Upland region (Altai Krai). Ukrainian Journal of Ecology, 10(5), 177-185. 